\title{
Small, Stable Shuttle Vectors Based on the Minimal pVS1 Replicon for Use in Gram-Negative, Plant-Associated Bacteria
}

\author{
Stephan Heeb, ${ }^{1}$ Yoshifumi Itoh, ${ }^{2}$ Takayuki Nishijyo, ${ }^{2}$ Ursula Schnider, ${ }^{1}$ Christoph Keel, ${ }^{1}$ Julie Wade, ${ }^{3}$ \\ Ultan Walsh, ${ }^{3}$ Fergal O'Gara, ${ }^{3}$ and Dieter Haas ${ }^{1}$ \\ ${ }^{1}$ Laboratoire de Biologie Microbienne, Université de Lausanne, $\mathrm{CH}-1015$ Lausanne, Switzerland; 'Division \\ of Applied Microbiology, National Food Research Institute, Tsukuba, Ibaraki 305-8642, Japan; \\ ${ }^{3}$ Microbiology Department, National University of Ireland, Cork, Ireland \\ Accepted 15 October 1999.
}

\begin{abstract}
The minimal replicon of the Pseudomonas plasmid pVS1 was genetically defined and combined with the Escherichia coli p15A replicon, to provide a series of new, oligocopy cloning vectors $(5.3$ to $8.3 \mathrm{~kb})$. Recombinant plasmids derived from these vectors were stable in growing and nongrowing cells of root-colonizing $P$. fluorescens strains incubated under different environmental conditions for more than 1 month.
\end{abstract}

Additional keywords: biocontrol, industrial biotransformation processes, mobilization, partitioning, rhizosphere.

The replicon of the 29-kb Pseudomonas plasmid pVS1 (Stanisich et al. 1977) is stably maintained in proteobacteria of many genera including Pseudomonas, Agrobacterium, Rhizobium, Burkholderia, Aeromonas, and Comamonas (Itoh et al. 1984) and for this reason has been widely used to construct cloning vectors that are suitable for plant-associated bacteria (Deblaere et al. 1987; Hajdukiewicz et al. 1994; Itoh and Haas 1985; Van den Eede et al. 1992; Van der Bij et al. 1996). The exquisite stability of these vectors is particularly useful when antibiotic selection of recombinant plasmids is impractical, e.g., in studies on rhizobacteria colonizing plant roots over a period of several days (Van der Bij et al. 1996) or, as we show here, over several weeks. Cloning vectors derived from pVS1 are also appreciated in industrial biotransformation processes (Zimmermann et al. 1997) and gene expression studies (Fukushima et al. 1996; Ishii et al. 1994).

Plasmid pVS1 does not replicate in Escherichia coli (Itoh et al. 1984). First generation pVS1 vectors containing just the pVS1 replication (rep) and stability (sta) region (Itoh and

Corresponding author: D. Haas, Laboratoire de Biologie Microbienne, Université de Lausanne, CH-1015 Lausanne E-mail: Dieter.Haas@1bm.unil.ch

Nucleotide and/or amino acid sequence data are to be found at the GenBank data bank as accession numbers AF118810 (pME6010), AF133828 (pME6011), AF133829 (pME6012), AF133830 (pME6030), AF118811 (pME6031), AF133831 (pME6040), and AF118812 (pME6041).
Haas 1985) could therefore not be used for gene cloning in $E$. coli (Darzins and Casadaban 1989; Itoh et al. 1988), although they could serve as suicide plasmids in this bacterium (Dunn 1991). Second generation pVS1-p15A or pVS1-ColE1 shuttle vectors could be used in $E$. coli and proved suitable for plantassociated bacteria (Loper and Lindow 1994; Van den Eede et al. 1992; Van der Bij et al. 1996), but were larger (12 to $15 \mathrm{~kb}$ ) than necessary. The aim of this work was to define genetically the minimal pVS1 replicon that is needed for stable maintenance in Pseudomonas fluorescens and to use this element for the construction of new, small, pVS1-p15A shuttle vectors. These were stable in $P$. fluorescens colonizing plant roots in natural soil for more than 1 month and proved suitable for the construction of recombinant strains to be used under environmental conditions.

\section{Sequence analysis of the minimal pVS1 replicon.}

The nucleotide sequence of the 3.8-kb rep sta region of pVS1 was determined by Hajdukiewicz et al. (1994), but not analyzed further. We confirmed the sequence except for an extra G occurring at position 2249 (GenBank accession numbers U10456 to U10463 and U10487 to U10491). We incorporated the rep sta region on a BamHI-StuI fragment from pME290 (Itoh and Haas 1985) into the new vector pME6010 (Fig. 1). This fragment contains five apparent open reading frames (ORFs). These were analyzed with the University of Wisconsin Genetics Computer Group (GCG) package, version 9.1. ORF1 (228 codons) showed similarity with the resolvase family of site-specific recombinases, e.g., $60 \%$ identity with Pin invertase of E. coli (Plasterk and van de Putte 1985) and $51 \%$ identity with resolvase of transposon $\operatorname{Tn} 3$ (Heffron et al. 1979). In pVS1, ORF1 is immediately adjacent to integron In0 (Brown et al. 1996). No obvious similarity with proteins in the Swissprot and EMBL data bases was found for ORF2 (71 codons). The following ORF termed staA consists of 209 codons and is located in the sta region, which is essential for segregational stability (Itoh et al. 1984; see below). The deduced StaA protein is $42 \%$ identical with the IncC 2 protein of the IncP $\alpha$ plasmid RK2 (Jagura-Burdzy et al. 1999; Motallebi-Veshareh et al. 1990) and has a nucleotide binding mo- 

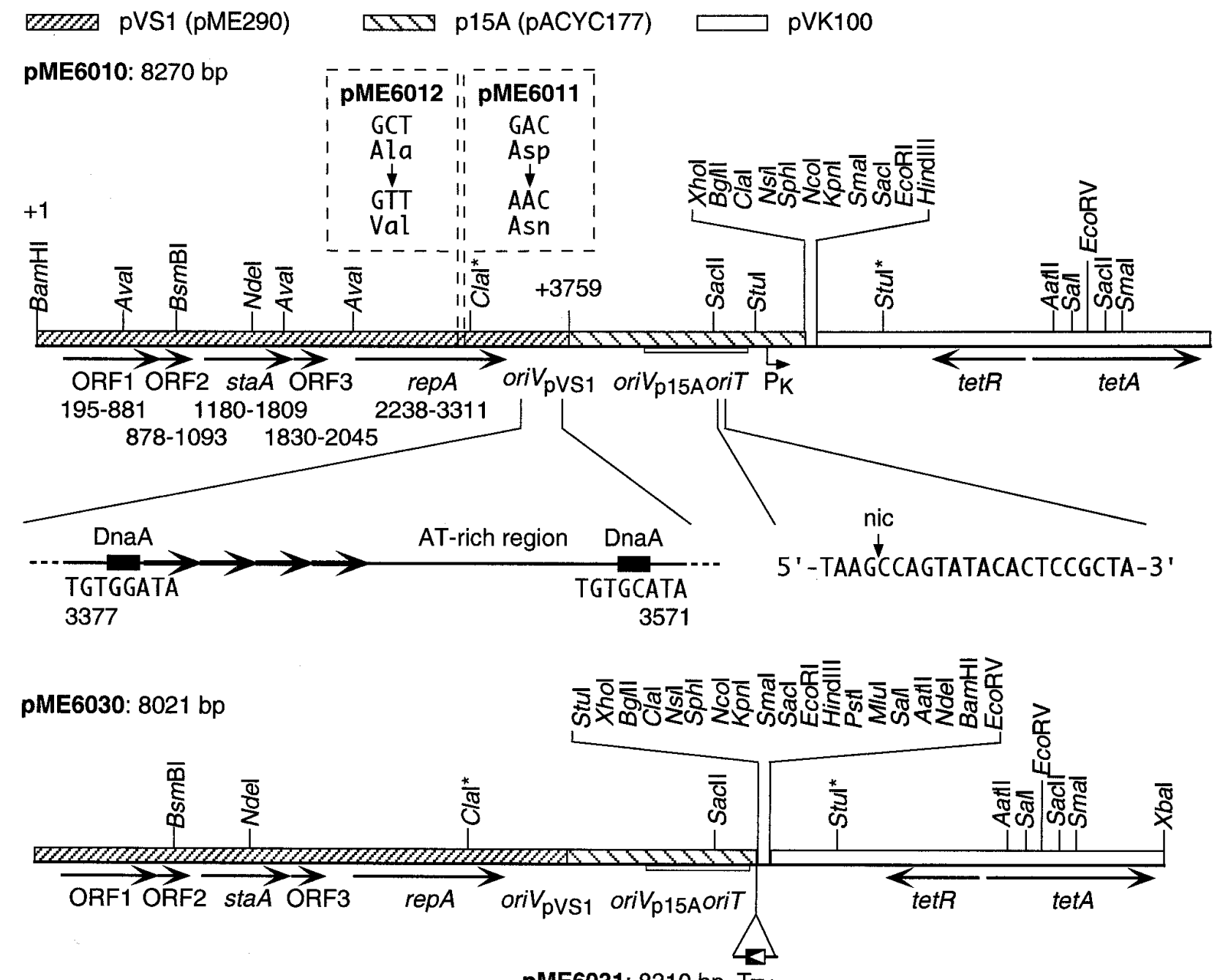

pME6031: 8310 bp TT4

pME6040: 5303 bp
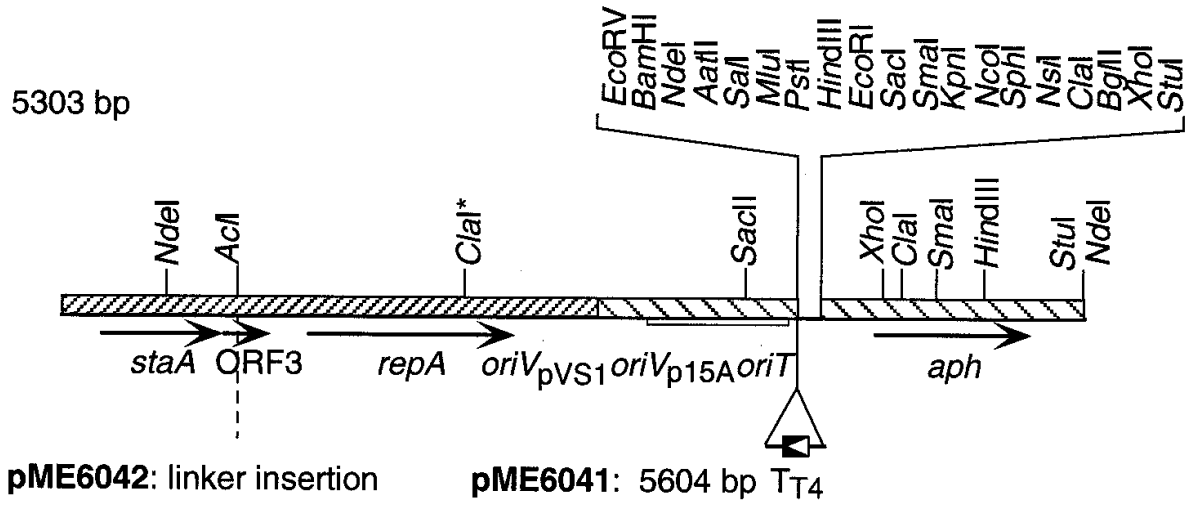

Fig. 1. Maps of the newly constructed pVS1-p15A shuttle vectors. Origins of plasmid fragments used are indicated at the top. Multiple cloning sites are derived from pUK21 (Vieira and Messing 1991). The pME6010 map shows only those AvaI sites located in the pVS1 moiety and used previously to localize the sta region (Itoh et al. 1984). In pME6010, the ColE1-like origin of transfer (oriT) of p15A contains a deduced nic site (Wilkins and Lanka 1993). The pVS1 origin of replication (oriV) consists of two DnaA boxes surrounding four 21-bp directed repeats (consensus: 5'-CGTACATTGGG AACC(CG)(AG)(AT)(AC)(GCA)C-3') and an AT-rich region. PK, constitutive kanamycin resistance promoter; TT4, T4 transcription terminator; aph, aminoglycoside phosphotransferase, conferring resistance to kanamycin. Cla $\mathrm{I}^{*}$ and $\mathrm{StuI}^{*}$ sites are methylated in dam $^{+}$ and $\mathrm{dcm}^{+}$strains, respectively. 
tif as well as two motifs that are conserved in partitioning proteins (Fig. 2). ORF3 (71 codons), which also lies in the sta region, has no apparent similarity with other known proteins. The 1.55-kb rep segment (Itoh et al. 1984) contains one ORF (repA) of 357 codons having $51 \%$ identity with the RepA protein of the Erwinia stewartii plasmid pSW500 (Fu et al. 1996), followed by a DnaA box, four direct repeats of 21 bp each (iterons), an AT-rich region, and a second DnaA box (Fig. 1). This sequence organization is typical of an origin of replication (oriV). By analogy with better-characterized plasmids such as RK2, P1, or F, the RepA protein of pVS1 may bind to the iterons and thereby sustain DnaA-assisted melting of the AT-rich region, which could serve as an entry site for the replication machinery (Abeles et al. 1995; Kawasaki et al. 1996; Pansegrau et al. 1994).

\section{Third generation pVS1 cloning vectors.}

The pVS1-p15A shuttle vector pME6010 (8.3 kb) replicates in $E$. coli owing to the p15A (pACYC177) moiety and features a multiple cloning site downstream of a constitutive kanamycin resistance promoter $\left(\mathrm{P}_{\mathrm{k}}\right)$ and a repressible tetracycline resistance $\left(\mathrm{Tc}^{\mathrm{r}}\right)$ determinant from RK2 (Fig. 1). Derivatives of pME6010 having a lower copy number (pME6011) or a higher copy number (pME6012) in Pseudomonas spp. were constructed by recruiting the mutated rep sta fragments from pME292 and pME294, respectively (Itoh et al. 1988). $\mathrm{P}_{\mathrm{k}}$ was deleted in the pME6010 derivatives pME6030 and pME6031 (which contains a transcription terminator inserted between the multiple cloning site and the p15A oriV). In pME6040 and pME6041 the $\mathrm{Km}^{\mathrm{r}}$ gene of pACYC177 was used instead of the $\mathrm{Tc}^{\mathrm{r}}$ determinant, and ORFs 1 and 2 are absent (Fig. 1).

\section{Plasmid stability in vitro.}

Vectors pME6010, pME6012, pME6030, and pME6040 were $100 \pm 0 \%$ stable in the biocontrol strain P. fluorescens CHA0 (Stutz et al. 1986) growing at $30^{\circ} \mathrm{C}$ in nutrient yeast broth without antibiotic selection for 100 generations, according to the procedure described by Itoh et al. (1984). Thus, in agreement with previous genetic analysis (Itoh et al. 1984) and as shown by the stability of pME6040, ORFs 1 and 2 are not needed for segregational stability of the pVS1 replicon. Furthermore, Itoh et al. (1984) have shown that AvaI deletions removing the $5^{\prime}$ part of $s t a A$ or both staA and ORF3 result in loss of stability. In pME6040, a 119-bp deletion was constructed extending from the $3^{\prime}$ part of staA to the AclI site in
ORF3 (Fig. 1). This was done by opening pME6040 at the unique $A c l$ I site and transforming E. coli DH5 $\alpha$ (Sambrook et al. 1989) with the linearized plasmid. The resulting deletion plasmid was maintained by only $45 \%$ of the CHA0 cells after 100 generations, confirming the importance of this region for segregational stability. Insertional inactivation of ORF3 by a linker carrying translational stops (pME6042; Fig. 1) did not affect plasmid stability but appeared to inhibit growth of the $P$. fluorescens host transiently. This phenomenon was not analyzed further. In conclusion, the similarity of StaA with the partitioning (Par) proteins IncC, SopA, and ParA of plasmids RK2, F, and P1, respectively (Motallebi-Veshareh et al. 1990; Niki and Hiraga 1997; Youngren and Austin 1997), suggests that StaA is a partitioning protein, whereas the role of ORF3 remains unclear.

Finally, the low-copy-number plasmid pME6011 was found to be unstable in P. fluorescens (complete loss within 60 generations without antibiotic selection); this effect can be explained by a mutation in repA (see below).

\section{Copy number determination.}

The adenine-auxotroph $P$. fluorescens CHA15 was transformed with pME6010 or pME6012 and grown aerobically in $8 \mathrm{ml}$ of succinate minimal medium (Meyer and Abdallah 1978) containing $50 \mu \mathrm{M}\left[2-{ }^{3} \mathrm{H}\right]$ adenine (specific activity 100 $\mu \mathrm{Ci} / \mu \mathrm{mol})$ at $30^{\circ} \mathrm{C}$ for 12 to $18 \mathrm{~h}$. From washed cells, total DNA was extracted by a $30 \mathrm{~min}$ incubation at $37^{\circ} \mathrm{C}$ in $\mathrm{TE}$ buffer (Sambrook et al. 1989) containing 2.5\% (wt/vol) sodium dodecyl sulfate and $2.5 \mathrm{mg}$ of RNaseA per ml. After a $2 \mathrm{~h}$ treatment with proteinase $\mathrm{K}(2.5 \mathrm{mg} / \mathrm{ml})$, DNA was isolated by phenol-chloroform extraction and ethanol precipitation (Gamper et al. 1992). DNA (ca. $10 \mu \mathrm{g}$ ) was digested in $25 \mu \mathrm{l}$ of reaction buffer with EcoRI (cuts pME6010 and pME6012 once) and PstI (does not cut the plasmids), then 4 $\mu \mathrm{l}$ of loading buffer (Sambrook et al. 1989) was added. Radioactivity of total DNA was determined in $2 \mu \mathrm{l}$, and the remaining part $(26 \mu \mathrm{l})$ was electrophoresed in a $0.7 \%$ agarose gel. The 8.3-kb plasmid band was well separated from the bulk of faster moving chromosomal fragments, cut out from the gel, dissolved in $1 \mathrm{ml}$ of $\mathrm{H}_{2} \mathrm{O}$ by boiling, and measured in a liquid scintillation counter. Plasmid copy numbers $(n)$ were calculated from the ratio of ${ }^{3} \mathrm{H}$-labeled plasmid DNA to ${ }^{3} \mathrm{H}$-labeled chromosomal DNA (= total DNA - plasmid DNA), taking into account the size of the plasmid $(8.3 \mathrm{~kb})$ and the estimated size of the chromosome (6,630 kb; Rainey and Bailey 1996). Copy numbers were $n$

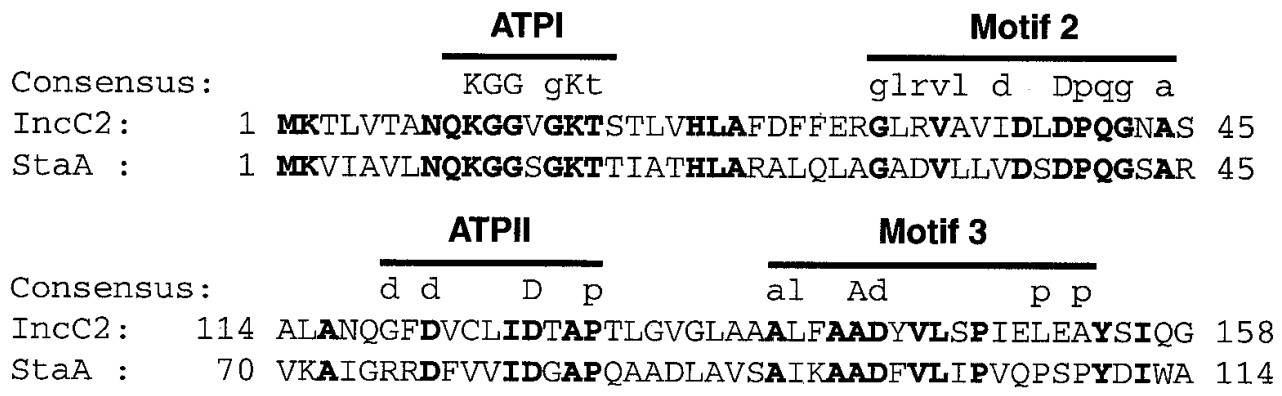

Fig. 2. Alignment of the conserved regions of the IncC2 protein of plasmid RK2 and the deduced StaA protein of pVS1. Two ATP-binding sites and the two other motifs typical of the ParA family of partitioning proteins are indicated. Highly conserved residues are shown in uppercase; less conserved residues appear in lowercase (Motallebi-Veshareh et al. 1990). Identical residues in StaA and IncC2 are shown in bold. 
$=5.9 \pm 1.8$ for pME6010 and $n=13.8 \pm 3.4$ for pME6012 (mean values of 8 experiments \pm standard deviation). These values are in good agreement with the estimated copy numbers of the parental plasmids pME290 $(n=5$ to 7 and pME294 ( $n=12$ to 21 ) in P. aeruginosa (Itoh et al. 1988). Plasmid DNA yields of pME6010, pME6031, and pME6041 showed no apparent differences, indicating that the copy numbers of these plasmids are similar.

The mutation causing an elevated copy number of pME294 and pME6012 was mapped to the repA gene (Ala-246 $\rightarrow$ Val) (Fig. 1). The mutation causing a low copy number and instability of pME292 and pME6011 was also located in repA (Asp-260 $\rightarrow$ Asn; Fig. 1). It is known from variants of other plasmids (e.g., Rts1 or pSC101) that point mutations in the repA replication gene can cause variations in plasmid copy numbers (Xia et al. 1993; Yonemitsu et al. 1995).

\section{Mobilization of pME6010.}

The p15A replicon contains a 22-bp sequence that is identical with the origin of transfer (oriT) of ColE1 plasmids (Wilkins and Lanka 1993). This sequence accounts for the mobilization of the p15A vector pACYC184 by pRK2013, which is a ColE1 plasmid carrying its own mob genes plus the RK2 tra genes (Comai et al. 1983; B. Ganter and D. Haas, unpublished data). Owing to this oriT, E. coli DH5 // pME6010 + pRK2013 transferred pME6010 to E. coli HB101 (with an efficiency of $5 \times 10^{-4}$ transconjugants per donor) and to $P$. aeruginosa PAO1 (with $2 \times 10^{-4}$ transconjugants per donor), but not to $P$. fluorescens CHA0, this bacterium being refractory to conjugation with natural IncP $\alpha$ plasmids (Voisard et al. 1988). However, all shuttle vectors constructed could readily be introduced into strain $\mathrm{CHAO}$ by electroporation.

\section{Stability of the vector and recombinant plasmids in root colonizing bacteria incubated in natural soil.}

A translational $l a c Z$ fusion to the $h c n A$ (hydrogen cyanide synthase subunit A) gene of $P$. fluorescens $\mathrm{CHA} 0$ has been used previously to study anaerobic regulation of this biocontrol function (Laville et al. 1998). A pME6010 derivative carrying the $h c n A^{\prime}-$ lacZ fusion, pME3219 (Laville et al. 1998), the vector pME6010 alone, and pME6040 (Fig. 1) were tested for stability in the rifampicin-resistant strain CHA0-Rif colonizing the rhizosphere of wheat in natural soil; incubation conditions were essentially the same as those described before (Natsch et al. 1994). Two parallel inocula of ca. $10^{7} \mathrm{CFU}$ per $\mathrm{g}$ of soil were each applied to nine wheat plants; after 10, 20, and 30 days of incubation, strain CHA0-Rif carrying each of the plasmids was reisolated from the roots of $2 \times 3$ plants by plating on nutrient agar amended with $100 \mu \mathrm{g}$ of rifampicin per $\mathrm{ml}$; root colonization was between $2 \times 10^{5}$ and $9 \times 10^{7}$ CFU per g. Plasmid stability was determined by testing 136 colonies isolated from each plant for inheritance of the plasmid markers $\left(\mathrm{Tc}^{\mathrm{r}}, \beta\right.$-galactosidase activity, or $\left.\mathrm{Km}^{\mathrm{r}}\right)$. The vector pME6010 was $100 \pm 0 \%$ stable over the entire period of 30 days. The recombinant pME3219 was $99.4 \pm 0.7 \%$ stable during the same period. By contrast, pME6040 was maintained in $82.5 \pm 13.4 \%$ (10 days), $70.7 \pm 26.1 \%$ (20 days), and $69 \pm 30 \%$ (30 days) of cells tested. This instability, which was not apparent in a rich culture medium, might be due to a slight metabolic burden caused by the constitutively expressed $\mathrm{Km}^{\mathrm{r}}$ gene of pME6040, whereas in pME6010 the $\mathrm{Tc}^{\mathrm{r}}$ gene is repressed in the absence of the antibiotic.

2,4-Diacetylphloroglucinol (Phl) is an important biocontrol factor produced by many fluorescent pseudomonads. The Phl biosynthetic genes phlACBDE form an operon that is controlled by the product of the divergently transcribed $p h l F$ gene (Bangera and Thomashow 1999). An 8.3-kb EcoRI fragment carrying the phlACBDE genes, but not the phlF regulatory gene, from $P$. fluorescens F113 (Cronin et al. 1997) was inserted into the EcoRI site of pME6010, giving pCU8.3. This recombinant plasmid when introduced into strain F113Rif resulted in overproduction of $\mathrm{Phl}$ in vitro (data not shown). The stability of pME6010 and pCU8.3 in P. fluorescens F113Rif was determined in a microcosm trial with sugarbeet sown in soil naturally infested with the phytopathogenic fungus $P y$ thium ultimum. The two strains (i.e., F113Rif/pME6010 and F113Rif/pCU8.3) were inoculated onto sugarbeet seeds (Beta vulgaris cv. Accord) as previously described (Fedi et al. 1997). Twelve sugarbeet seeds were sown per pot and placed in a growth chamber set at $12^{\circ} \mathrm{C}$ with $16 \mathrm{~h}$ light. Thirty-five days after sowing, seedlings were removed from pots (four seedlings per treatment from different pots). Bacteria were isolated from rhizosphere extracts by plating on selective sucrose asparagine medium (Scher and Baker 1982) containing ampicillin $(50 \mu \mathrm{g} / \mathrm{ml})$, rifampicin $(100 \mu \mathrm{g} / \mathrm{ml})$, and cycloheximide $(100 \mu \mathrm{g} / \mathrm{ml})$. Plasmid stability was determined by transferring 200 isolates of each strain to the same medium amended with tetracycline $(75 \mu \mathrm{g} / \mathrm{ml})$. All strains grew on the selective medium containing tetracycline, indicating $100 \pm 0 \%$ stability for pME6010 and pCU8.3 in P. fluorescens F113Rif after 35 days in the sugarbeet rhizosphere.

In the rhizosphere, $P$. fluorescens is metabolically active and grows. It was of interest to check plasmid stability also under soil conditions not allowing substantial bacterial growth. A rifampicin-resistant $\operatorname{alg} U(=\operatorname{alg} T)$ mutant lacking the stress sigma factor $\sigma^{22}\left(=\sigma^{\mathrm{E}}\right)$, CHA212-Rif (Schnider et al. 1997), and a pME6010 derivative carrying the $\operatorname{alg} U^{+}$gene, pME6221, were used in a survival test in natural, nonsterile soil from Eschikon (Natsch et al. 1994) with $27 \%$ water content. After 30 days of incubation, strains CHA0-Rif, CHA212Rif/pME6010, and CHA212-Rif/pME6221 all showed a similar, $1 \log$ loss of viability, suggesting that $\sigma^{22}$ function was not essential under these conditions. Importantly, both the vector pME6010 and the recombinant plasmid pME6221 were 92 to $100 \%$ stable in this experiment.

\section{Concluding remarks.}

As shown by the above tests conducted under different environmental conditions, excellent stability characteristics make pME6010, pME6030, and pME6040 and their derivatives highly suitable for plant-microbe interaction studies as well as for industrial applications in pseudomonads and related genera. The incompatibility group of the pVS1 replicon has not been determined. However, this replicon is compatible in $P$. aeruginosa with IncP-1 (= IncP in E. coli), IncP-4 (= IncQ in E. coli), IncP-8, IncP-10, and IncP-11 plasmids (Itoh and Haas 1985; Stanisich et al. 1977). It is therefore possible to use pVS1 vectors in combination with a variety of other replicons. Further derivatives of these vectors, e.g., suitable for the construction of translational $l a c Z$ or 'phoA fusions, are available from the authors on request. 


\section{ACKNOWLEDGMENTS}

We thank C. Blumer for providing plasmid pME3219, P. Michaux for assistance in the rhizosphere experiments, B. Ganter for localizing oriT on pACYC184, and P. Azelvandre for supplying CHA15. This work was supported by the Swiss Priority Program Biotechnology (no. 500204502311) and the European project IMPACT II (BIO4CT960027).

\section{LITERATURE CITED}

Abeles, A. L., Reaves, L. D., Youngren-Grimes, B., and Austin, S. J. 1995. Control of P1 plasmid replication by iterons. Mol. Microbiol. 18:903-912.

Bangera, M. G., and Thomashow, L. S. 1999. Identification and characterization of a gene cluster for synthesis of the polyketide antibiotic 2,4-diacetylphloroglucinol from Pseudomonas fluorescens Q2-87. J. Bacteriol. 181:3155-3163.

Brown, H. J., Stokes, H. W., and Hall, R. M. 1996. The integrons In0, In2, and In5 are defective transposon derivatives. J. Bacteriol. 178: 4429-4437.

Comai, L., Schilling-Cordaro, C., Mergia, A., and Houck, C. M. 1983. A new technique for genetic engineering of Agrobacterium Ti plasmid. Plasmid 10:21-30.

Cronin, D., Moënne-Loccoz, Y., Fenton, A., Dunne, C., Dowling, D. N., and O'Gara, F. 1997. Role of 2,4-diacetylphloroglucinol in the interactions of the biocontrol pseudomonad strain F113 with the potato cyst nematode Globodera rostochiensis. Appl. Environ. Microbiol. 63:1357-1361.

Darzins, A., and Casadaban, M. J. 1989. In vivo cloning of Pseudomonas aeruginosa genes with mini-D3112 transposable bacteriophage. J. Bacteriol. 171:3917-3925.

Deblaere, R., Reynaerts, A., Höfte, H., Hernalsteens, J.-P., Leemans, J., and Van Montagu, M. 1987. Vectors for cloning in plant cells. Methods Enzymol. 153:277-292.

Dunn, I. S. 1991. Pseudomonas aeruginosa plasmids as suicide vectors in Escherichia coli: Resolution of genomic cointegrates through short regions of homology. Gene 108:109-114.

Fedi, S., Tola, E., Moënne-Loccoz, Y., Dowling, D. N., Smith, L. M., and O'Gara, F. 1997. Evidence for signaling between the phytopathogenic fungus Pythium ultimum and Pseudomonas fluorescens F113: P. ultimum represses the expression of genes in P. fluorescens F113, resulting in altered ecological fitness. Appl. Environ. Microbiol. 63: 4261-4266.

Fu, J. F., Chang, H. C., Chen, Y. M., Chang, Y. S., and Liu, S. T. 1996. Characterization of the replicon of plasmid pSW500 of Erwinia stewartii. Mol. Gen. Genet. 250:699-704.

Fukushima, J., You, Z., Kurata, M., Kawamoto, S., Shigematsu, T., and Okuda, K. 1996. Regulation of elastase and alkaline protease gene expression in Pseudomonas aeruginosa. Pages 484-489 in: Molecular Biology of Pseudomonads. T. Nakazawa, K. Furakawa, D. Haas, and S. Silver, eds. American Society for Microbiology, Washington, DC.

Gamper, M., Ganter, B., Polito, M. R., and Haas, D. 1992. RNA processing modulates the expression of the $\operatorname{arcDABC}$ operon in Pseudomonas aeruginosa. J. Mol. Biol. 226:943-957.

Hajdukiewicz, P., Svab, Z., and Maliga, P. 1994. The small, versatile pPZP family of Agrobacterium binary vectors for plant transformation. Plant Mol. Biol. 25:989-994.

Heffron, F., McCarthy, B. J., Ohtsubo, H., and Ohtsubo, E. 1979. DNA sequence analysis of the transposon $\mathrm{Tn} 3$ : Three genes and three sites involved in transposition of Tn3. Cell 18:1153-1163.

Ishii, T., Fukushima, J., Fujita, S., Shigematsu, T., Ando, N., Ishiwata, T., Kurata, M., Kawamoto, S., Morihara, K., and Okuda, K. 1994. Elastase gene expression in non-elastase-producing Pseudomonas aeruginosa strains using novel shuttle vector systems. FEMS Microbiol. Lett. 116:307-313.

Itoh, Y., and Haas, D. 1985. Cloning vectors derived from the Pseudomonas plasmid pVS1. Gene 36:27-36.

Itoh, Y., Soldati, L., Leisinger, T., and Haas, D. 1988. Low- and intermediate-copy-number cloning vectors based on the Pseudomonas plasmid pVS1. Antonie van Leeuwenhoek 54:567-573.

Itoh, Y., Watson, J. M., Haas, D., and Leisinger, T. 1984. Genetic and molecular characterization of the Pseudomonas plasmid pVS1. Plasmid 11:206-220.
Jagura-Burdzy, G., Kostelidou, K., Pole, J., Khare, D., Jones, A., Williams, D. R., and Thomas, C. M. 1999. IncC of broad-host range plasmid RK2 modulates KorB transcriptional repressor activity in vivo and operator binding in vitro. J. Bacteriol. 181:2807-2815.

Kawasaki, Y., Matsunaga, F., Kano, Y., Yura, T., and Wada, C. 1996. The localized melting of mini-F origin by the combined action of the mini-F initiator protein (RepE) and HU and DnaA of Escherichia coli. Mol. Gen. Genet. 253:42-49.

Laville, J., Blumer, C., Von Schroetter, C., Gaia, V., Defago, G., Keel, C., and Haas, D. 1998. Characterization of the hcnABC gene cluster encoding hydrogen cyanide synthase and anaerobic regulation by ANR in the strictly aerobic biocontrol agent Pseudomonas fluorescens CHA0. J. Bacteriol. 180:3187-3196.

Loper, J. E., and Lindow, S. E. 1994. A biological sensor for iron available to bacteria in their habitats on plant surfaces. Appl. Environ. Microbiol. 60:1934-1941.

Meyer, J. M., and Abdallah, M. A. 1978. The fluorescent pigment of Pseudomonas fluorescens: Biosynthesis, purification and physicochemical properties. J. Gen. Microbiol. 107:319-328.

Motallebi-Veshareh, M., Rouch, D. A., and Thomas, C. M. 1990. A family of ATPases involved in active partitioning of diverse bacterial plasmids. Mol. Microbiol. 4:1455-1463.

Natsch, A., Keel, C., Pfirter, H. A., Haas, D., and Défago, G. 1994. Contribution of the global regulator gene gacA to persistence and dissemination of Pseudomonas fluorescens biocontrol strain CHA0 introduced into soil microcosms. Appl. Environ. Microbiol. 60:25532560 .

Niki, H., and Hiraga, S. 1997. Subcellular distribution of actively partitioning F plasmid during the cell division cycle in Escherichia coli. Cell 90:951-957.

Pansegrau, W., Lanka, E., Barth, P. T., Figurski, D. H., Guiney, D. G., Haas, D., Helinski, D. R., Schwab, H., Stanisich, V. A., and Thomas, C. M. 1994. Complete nucleotide sequence of Birmingham IncP $\alpha$ plasmids. Compilation and comparative analysis. J. Mol. Biol. 239: 623-663.

Plasterk, R. H., and van de Putte, P. 1985. The invertible P-DNA segment in the chromosome of Escherichia coli. EMBO J. 4:237-242.

Rainey, P. B., and Bailey, M. J. 1996. Physical and genetic map of the Pseudomonas fluorescens SBW25 chromosome. Mol. Microbiol. 19: $521-533$

Sambrook, J., Fritsch, E. F., and Maniatis, T. A. 1989. Molecular Cloning. A Laboratory Manual. 2nd ed. Cold Spring Harbor Laboratory, Cold Spring Harbor, NY.

Scher, F. M., and Baker, R. 1982. Effect of Pseudomonas putida and a synthetic iron chelator on induction of soil suppressiveness to Fusarium wilt pathogens. Phytopathology 72:1567-1573.

Schnider, U., Keel, C., Blumer, C., Michaux, P., Défago, G., and Haas, D. 1997. Regulation of mucoidy in the biological control agent Pseudomonas fluorescens $\mathrm{CHA} 0$ and construction of an exopolysaccharide-overproducing variant. Pages 349-352 in: Plant GrowthPromoting Rhizobacteria, Present Status and Future Prospects. A Ogoshi, K. Kobayashi, Y. Homma, F. Kodama, N. Kondo, and S. Akino, eds. OECD, Paris

Stanisich, V. A., Bennett, P. M., and Richmond, M. H. 1977. Characterization of a translocation unit encoding resistance to mercuric ions that occurs on a nonconjugative plasmid in Pseudomonas aeruginosa. $\mathrm{J}$. Bacteriol. 129:1227-1233.

Stutz, E. W., Défago, G., and Kern, H. 1986. Naturally occurring fluorescent pseudomonads involved in suppression of black root rot of tobacco. Phytopathology 76:181-185.

Van den Eede, G., Deblaere, R., Goethals, K., Van Montagu, M., and Holsters, M. 1992. Broad host range and promoter selection vectors for bacteria that interact with plants. Mol. Plant-Microbe Interact. 5: 228-234.

Van der Bij, A. J., De Weger, L. A., Tucker, W. T., and Lugtenberg, B. J. J. 1996. Plasmid stability in Pseudomonas fluorescens in the rhizosphere. Appl. Environ. Microbiol. 62:1076-1080.

Vieira, J., and Messing, J. 1991. New pUC-derived cloning vectors with different selectable markers and DNA replication origins. Gene 100: 189-194.

Voisard, C., Rella, M., and Haas, D. 1988. Conjugative transfer of plasmid RP1 to soil isolates of Pseudomonas fluorescens is facilitated by certain large RP1 deletions. FEMS Microbiol. Lett. 55:9-14.

Wilkins, B., and Lanka, E. 1993. DNA processing and replication during 
plasmid transfer between gram-negative bacteria. Pages 105-136 in: Bacterial Conjugation. D. B. Clewell, ed. Plenum, New York.

Xia, G., Manen, D., Yu, Y., and Caro, L. 1993. In vivo and in vitro studies of a copy number mutation of the RepA replication protein of plasmid pSC101. J. Bacteriol. 175:4165-4175.

Yonemitsu, H., Higuchi, H., Fujihashi, T., and Kaji, A. 1995. An unusual mutation in RepA increases the copy number of a stringently controlled plasmid (Rts1 derivative) by over one hundred fold. Mol. Gen.
Genet. 246:397-400.

Youngren, B., and Austin, S. 1997. Altered ParA partition proteins of plasmid P1 act via the partition site to block plasmid propagation. Mol. Microbiol. 25:1023-1030.

Zimmermann, T. P., Robins, K. T., Werlen, J., and Hoeks, F. W. J. M. M. 1997. Bio-transformation in the production of L-carnitine. Pages 287305 in: Chirality in Industry. Vol. II. A. N. Collins, G. N. Sheldrake, and J. Crosby, eds. J. Wiley \& Sons, New York. 